\title{
GENDER DIFFERENTIALS IN FARMERS' INVOLVEMENT IN CASSAVA PRODUCTION ACTIVITIES IN ABIA STATE, NIGERIA
}

\author{
${ }^{*}$ Nwwaobiala, C. U., ${ }^{2}$ Alozie, E. N. and ${ }^{3}$ Anusiem, C. N. \\ 1Department of Rural Sociology and Extension \\ 2Department of Home Science/Hospitality Management \\ Michael Okpara University of Agriculture Umudike, Abia State, Nigeria \\ 3Department of Agricultural Economics and Extension \\ National Open University of Nigeria, Kaduna Kaduna State, Nigeria
}

Corresponding e-mail: cunwaobiala@gmail.com

\begin{abstract}
This study assessed men and women differentials in cassava production activities in Abia State, Nigeria. A total of 120 cassava farmers comprising 60 men and 60 women were randomly selected. Data were collected with a structured questionnaire and analyzed using descriptive statistics, multiple regression and Z-test. Results show that the men had mean age of 44.5 years and 47 years for the women, majority $93.3 \%$ (men) and $81.6 \%$ (women) were married, most $61.6 \%$ (men) and $51.7 \%$ (women) attended secondary school and had mean farming experience of 14.9 years (men) and 12.7 years (women). The major sources of information on cassava production activities used by the farmers were Agricultural Development Programme (ADP) and fellow farmers. Results further showed that women were more involved $(\bar{x}=2.0)$ than the male cassava farmers $(\bar{x}=1.8)$ in cassava production activities. The factors that influenced the men's involvement in cassava production activities were household size, farm income and farm size whereas marital status, farming experience and education were the major factors that influenced women's participation in the process. Meanwhile, there was a significant difference in the level of involvement of the men and women farmers in cassava production activities at $1.0 \%$ level of probability. The study concludes that women are more involved in cassava production activities than men. This study therefore recommends formulation of gender sensitive policies, land reforms, free and affordable education for women farmers for enhanced cassava production.
\end{abstract}

Keywords: Gender, Differentials, Cassava, Production, Activities 


\section{INTRODUCTION}

Gender analysis of contribution to food output in rural households in Nigeria is an important aspect in the development of agriculture. This will ensure effective allocation of production resources within the rural households. Obinna and Nwaobiala (2015) noted that both men and women are involved in agricultural production activities taking into consideration the role they play. The problem of food shortages in Nigeria has been attributed to an acute dearth of male labour and a shift of farm responsibilities to the women following the findings of Olaoye (2014). There has also been a great disparity between women and men in the size of land holdings as well as their involvement in agricultural production (Agarwal, 2017).

Cassava is one of the major crops grown by the smallholder farmers in the southern and eastern part of Nigeria. At a growth rate of 5 per cent the annual cassava production in Nigeria has increased in 2014 from 38 million metric tons to 51million metric tons in the year 2017 (Federal Ministry of Agriculture \& Rural Development, 2018). Before the Nigerian Civil war in south eastern Nigeria, from 1967-1970, cassava was regarded as a women's crop (Lagat and Maina, 2017). The National Root Crops Research Institute Umudike and International Institute for Tropical Agriculture Ibadan developed many cassava technologies such as; site selection, selection of improved varieties, making of ridges, planting of angle $45^{\circ}$, date of planting, spacing, weeding, fertilizer application, time of harvest and processing activities and they were transferred to farmers through ADPs for adoption and utilization in order to maximize profit (National Root Crops Research Institute, 2012; International Institute for Tropical Agriculture, 2010). Literature suggests that men are involved in cassava production and processing even though their level of involvement cannot be compared to their female counterparts. In view of this assertion, Odebode and Adetunij (2015) affirmed that there are different roles adult and young male and female play in cassava production activities. Okpara (2015) noted that men and women perform different functions, have unequal decision-making power and differences in access to agricultural production. As a result of these differences, their decisions, views, needs and priorities to improve their productive potentials also differ. It is not certain whether the level of involvement of men and women in cassava production activities are the same, as there is dearth of information in this regard. Hence, this study was undertaken to analyze the differentials in the level of involvement of men and women in cassava production activities in Abia State, Nigeria. The specific objectives of the study were to (i) describe the socio-economic characteristics of men and women cassava farmers in the study area; (ii) identify the farmers' sources of information on 
cassava production activities; and to (iii) examine their involvement in cassava production activities.

\section{Hypotheses of the Study}

$\mathrm{HO}_{1}$ : Socio-economic characteristics of men and women cassava farmers do not influence their involvement in cassava production activities in the study area

$\mathrm{HO}_{2}$ : The involvement of male and female farmers in cassava production activities in the study area does not differ.

\section{METHODOLOGY}

\section{The Study Area}

The study area was Abia state, Nigeria. The state lies between Longitudes 7023' and 802' east of the Equator and Latitudes 4047' and 6012' north of the Greenwich Meridian. The state is located East of Imo state and shares common boundaries with Anambra, Enugu and Ebonyi States on the North West, North and North East respectively. It is bounded by Cross River and Akwa Ibom States on the East and Southeast and Rivers State to the South.

\section{Sampling Procedure and Sample Size}

A multistage random sampling technique was used to select the cassava farmers. In the selection, two agricultural zones - Umuahia and Aba - were randomly selected out of the three agricultural zones that make up the state. In Umuahia agricultural zone, Ikwuano and Umuahia North blocks were selected while in Aba zone, Osiisoma and Isiala Ngwa South blocks were selected to give a total of four blocks. Three circles were randomly selected from each of the four blocks to give a total of 12 circles. From the 12 circles, five (5) men and women cassava farmers each were randomly selected to give a total sample size of 120 cassava farmers, comprising 60 men and 60 women cassava farmers.

\section{Data Analysis}

Descriptive statistics such as frequency counts, percentages and mean scores were used to realize the objectives of the study while the hypotheses were tested with multiple regression and $\mathrm{Z}$ - test analyses. 


\section{Measurement of Variables}

In order to determine the levels of involvement of the men and women farmers in cassava production activities, a three-point Likert type rating scale of always $=3$, occasionally $=2$ and never $=1$ was used to measure their responses. The mean cut off mark was calculated by adding $3+2+1=6$ divided by 3 to give 2.0. The following decision rule was obtained thus:

1.00-1.50 (low), 1.51- 1.99 (moderate) and 2.0 and above (high)

\section{Model Specifications}

The four functional forms of regression-linear, exponential, double log and semi-log - were used to determine socio-economic factors influencing the farmers' involvement in cassava production activities in the study area. The four functional forms are explained in explicit form as:

The multiple regression analysis is stated thus

$Y=f\left(X_{1}, X_{2}, X_{3}, X_{4}, X_{5}, X_{6}, X_{7}, X_{8}, U_{i}\right)$

Where:

$Y=$ levels of involvement men or women in cassava production activities (measured by number of involvement scores of the respondents)

$X_{1}=$ age (years)

$X_{2}=$ household size (numbers)

$X_{3}=$ farm income (naira)

$X_{4}=$ marital status ( married $=1$, otherwise $=0$ )

$X_{5}=$ farm size (hectares)

$X_{6}=$ farming experience (years)

$X_{7}=$ education (years)

$X_{8}=$ extension contact (numbers)

$\mathrm{u}_{\mathrm{i}}=$ error term.

i. The mean difference of involvement of men and women in cassava production activities in the study area was tested using Z-test analysis 
The model for Z-test analysis of comparison is specified thus:

$$
Z=\frac{\bar{X}_{1}-\bar{X}_{2}}{\sqrt{\frac{\sigma_{1}^{2}}{n_{1}}+\frac{\sigma_{2}^{2}}{n_{2}}}}
$$

$n_{1}+n_{2}-2$ degrees of freedom

Where

"Z" = "Z" statistic

$\bar{X}_{1}=$ sample mean of men involvement in cassava production activities

$\bar{X}_{2}=$ sample mean of women involvement in cassava production activities

$\sigma^{2}{ }_{1}=$ standard deviation of men involvement in cassava production activities

$\sigma{ }_{2}=$ standard deviation of women involvement in cassava production activities

$n_{1}=$ sample size for men cassava farmers

$n_{2}=$ sample size for women cassava farmers

\section{RESULTS AND DISCUSSION}

\section{Socio-economic Characteristics of the Farmers}

Table 1 shows the socio-economic characteristics of the farmers. The table shows that the mean age of the men was 44.5 years and 47 years for the women. These results imply that the farmers were young, active and capable of undertaking activities involved in cassava farming. Michael (2014) posited that people of this age group constitute the major agricultural productive workforce. The majority of the farmers were married. 
Table 1: Selected socio-economic characteristics of the respondents in the study area

\begin{tabular}{lcccc}
\hline Variables & Men $(\mathbf{n}=\mathbf{6 0})$ & $\begin{array}{c}\text { Standard } \\
\text { Deviation }\end{array}$ & Women $(\mathbf{n = 6 0 )}$ & $\begin{array}{c}\text { Standard } \\
\text { Deviation }\end{array}$ \\
\hline Age (years) & 44.5 & \pm 39.7 & 47 & \pm 42.8 \\
Marital Status (\%) & 93.3 & & 81.6 & \\
Education (secondary) (\%) & 61.6 & & 51.7 & \\
Household Size (numbers) & 6.5 & \pm 4.8 & 6.2 & \pm 4.4 \\
Farming Experience (years) & 14.9 & \pm 12.6 & 12.7 & \pm 10.4 \\
Farm Size (hectares) & 1.6 & \pm 1.0 & 1.1 & \pm 0.7 \\
\hline
\end{tabular}

Source: Field Survey, 2018

About $62 \%$ of the men had secondary education while $51.7 \%$ of the women did. This result suggests that the farmers were literate and should have little or no difficulties in understanding, accepting and adopting innovations relating to cassava production. Nwaobiala (2017) reported that level of education of farmers enhances acceptance of innovations.

The mean farming experience of the men was 14.9 years while it was 12.7 years for the women. Experience gained by farmers in agricultural production activities helps them to bear the risk and uncertainties associated with farming. This concurs with the findings of Effiong, Ayanam and Umoh (2012) who reported that farmers' years of experience equips them to absorb shocks in farming.

The mean farm sizes of the respondents were 1.6 hectares for the men and 1.1 hectares for the women. This is expected because of the culture in the study area that suggests that women's right to land is not customary in Igbo land. The size of the land implies that the farmers were small scale farmers. This agrees with the findings of Arifin and Nirawal (2018).

The mean household size for the male farmers was 6.5 persons, while for the women it was 6.2 persons. Households has shown to be suppliers of farm labour for all farming activities. This result is in tandem with the findings of Aniedu (2016) who posited that the size of the household supplements farm labour thereby reducing cost.

\section{Sources of Information on Cassava Production Technologies}

Table 2 shows the distribution of the farmers according to their sources of information on cassava production technologies. The table shows that the majority of them, comprising $93.3 \%$ of the men and $81.7 \%$ of the women, sourced information on cassava production technologies from Agricultural Development Programmes (ADP). Similarly, $90 \%$ of the men and $88.3 \%$ of the 
women sourced same from fellow farmers. The result suggests that fellow farmers who may be Agricultural Development Programme contact farmers play complementary role in disseminating innovations. The use of mass media is one of the fastest methods of technology dissemination, thereby informing farmers on latest available innovations (Badiru and Yekini, 2015).

Table 2: Distribution of respondents according to sources of information on cassava production technologies

\begin{tabular}{lcccc}
\hline & \multicolumn{2}{c}{ Men $(\mathbf{n}=\mathbf{6 0})$} & \multicolumn{2}{c}{ Women $(\mathbf{n = 6 0})$} \\
Sources & Frequency & Percentage* & Frequency & Percentage* \\
\hline Ministry of Agriculture/ ADP & 56 & 93.3 & 49 & 81.7 \\
Seminars/Workshops & 7 & 11.7 & 9 & 15 \\
Research Institutes & 10 & 16.7 & 15 & 25 \\
Television programmes & 34 & 56.7 & 20 & 33.3 \\
Radio programmes & 38 & 63.3 & 39 & 65 \\
Fellow famers & 54 & 90 & 53 & 88.3 \\
Personal observations & 33 & 55 & 30 & 50 \\
\hline
\end{tabular}

Source: Field Survey, 2018

*Multiple Responses Recorded 


\section{Involvement of Men in Cassava Production Activities}

Figure 1 shows the pictorial representation of the level of men's involvement in cassava production activities. The figure shows that male cassava farmers were involved in site selection $(\bar{x}=2.2)$ and making of ridges, planting date, planting spacing, fertilizer application and time of planting with mean scores of $\bar{x}=2.0$ respectively. The results infer that men farmers were moderately involved $(\bar{x}=1.8)$ in cassava production activities. The result is in conformity with the findings of Okoroafor and Nwaobiala, (2014) who obtained a similar result among cassava farmers and processors in Abia state, Nigeria.

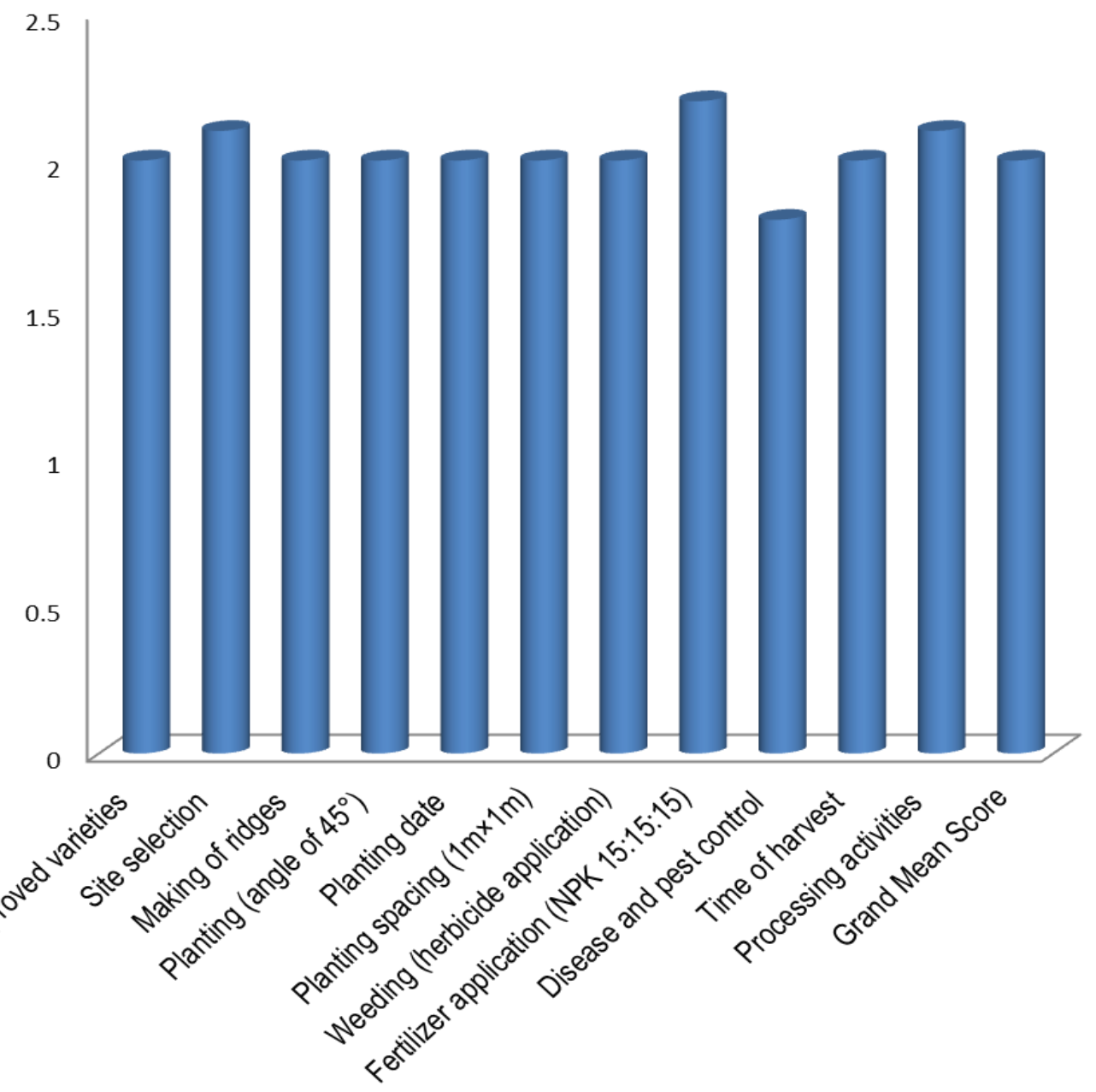

Figure 1: Mean Scores of Men Involvement in Cassava Production Activities 


\section{Involvement of Women in Cassava Production Activities}

Figure 2 shows the involvement of women in cassava production activities. The result revealed that female cassava farmers were involved in site selection $(\bar{x}=2.1)$ and selection of improved varieties, making of ridges, planting of angle $45^{\circ}$, date of planting, spacing, weeding, fertilizer application, Time of harvest and processing activities with mean score of $\bar{x}=2.0$ respectively. The grand mean score of female farmers were 2.0., indicating that women farmers were more involved than male farmers in cassava production activities in the study area. This result is in tandem with the findings of Etuk, Udoe and Okon (2018) and Nwakor et al., (2016) as they infer that women are more actively involved in both cassava production and processing activities in Nigeria.

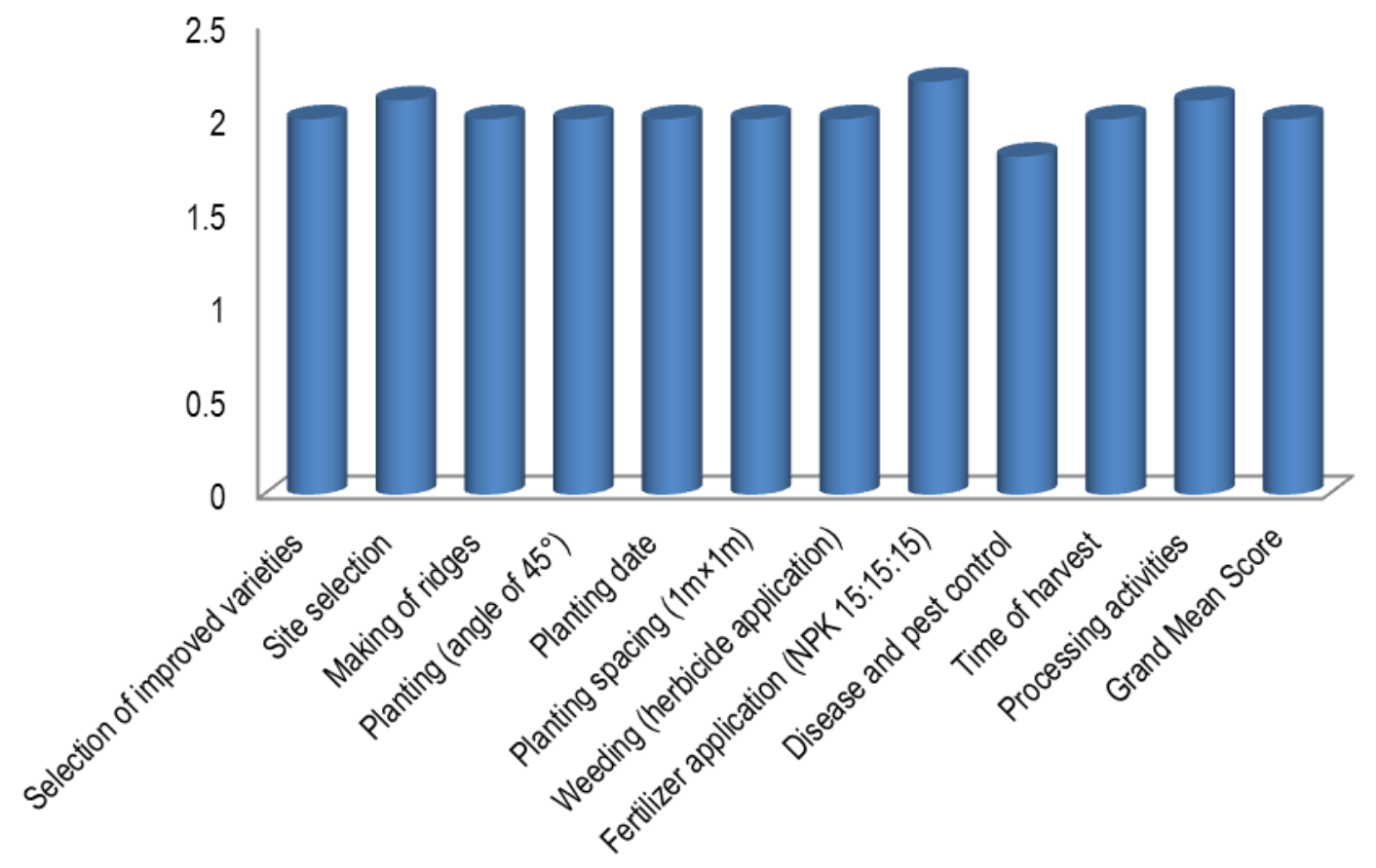

Figure 2: Mean Scores of Women Involvement in Cassava Production Activities 


\section{Determinants of the Level of Involvement of Men and Women Farmers in Cassava Production Activities}

Table 3 shows the regression estimates of the determinants of men and women farmer's involvement in cassava production activities in the study area. The linear functional form was chosen on the lead because of higher $\mathrm{R}^{2}$ value, number of significant factors and agreement with a priori expectation. The $R^{2}$ values of 0.5343 (men) and 0.5331 (women) explained $53.43 \%$ and $53.31 \%$ of the variation in their levels of involvement in cassava production activities in the study area. The $F$ value of 1.91 (men) and 1.94 (women) were significant at $10 \%$ level of probabilities indicating goodness of fit of the regression line.

Table 3: Linear regression estimates of the determinants of men and women cassava farmers' involvement in cassava production activities.

\begin{tabular}{lcl}
\hline Variables & Men & \multicolumn{1}{c}{ Women } \\
\hline Constant & $-0.7274(-0.06)$ & $14.5267\left(5.44^{* * *}\right)$ \\
Age & $0.1797(1.22)$ & $0.0147(0.27)$ \\
Household size & $0.8135\left(1.88^{*}\right)$ & $0.1164(0.66)$ \\
Farm income & $0.00006\left(3.13^{* * *}\right)$ & $-9.96 \times 10-7(-0.25)$ \\
Marital Status & $5.4887(1.38)$ & $1.9073\left(2.93^{* *}\right)$ \\
Farm size & $4.4333\left(3.64^{* *}\right)$ & $0.2425(0.46)$ \\
Farming experience & $0.1569(0.42)$ & $0.1449\left(2.83^{* *}\right)$ \\
Education & $-0.1218(-0.33)$ & $0.1455\left(2.98^{* *}\right)$ \\
Extension contact & $-0.6632(-0.75)$ & $0.2760(0.60)$ \\
R2 & 0.5343 & 0.5331 \\
Pseudo R & 0.4118 & 0.4128 \\
F- ratio & $1.91^{*}$ & $1.94^{*}$ \\
\hline
\end{tabular}

Source: Stata Result Output

${ }^{*} P \leq 10,{ }^{* *} P \leq 0.5$ and ${ }^{* * *} P \leq 0.1$

The coefficient of household size of the men farmers was positive and significant at $1.0 \%$ level of probability. This implies that any increase in household size will lead to a correspondent increase in the level of involvement in cassava production activities among the male farmers in the study area. This is expected because large household sizes may serve as a means of cheap labour for cassava production activities in the study area. This result is in consonance with Nwaobiala 
(2018) who noted that relative large household size enhances the availability of labour for increased efficiency among farmers.

The coefficient of farm income of the male farmers was positive and significant at 1.0\% level of probability. This implies that any increase in farm income will lead to a corresponding increase in their level of involvement in cassava production activities in the study area. This result agrees with the findings of Umunakwe et al. (2016) as they opined that farm income realized from any farming activity increases the levels of involvement.

The coefficient of farm size (men) was also positive and significant at $5.0 \%$ level of probability. This implies that any increase in farm size will lead to a corresponding increase in level of involvement in men cassava production activities in the study area. Farmers operating larger farms tend to have greater financial resources and access to credit to get more involved in cassava production activities. This corroborates the findings of Onyeneke et al. (2016) who suggested that farm size influences involvement of farmers in any farming activity.

In the female category, the coefficient of marital status was positive and significant at $5.0 \%$ level of probability. This implies that any increase in the number of women farmers whom were married will lead to a corresponding increase in the level of involvement in cassava production activities among the female farmers in the study area. This is expected probably because spouses make effective and better decisions and play different roles in production activities in the study area this result is in tandem with Tijani, Tijani and Audu (2018) who reported that decision by married people facilitate level of participation in cassava farming thereby reducing the constraint therein.

The coefficient of farming experience was also positive and significant at $5.0 \%$ level. This implies that any increase in farming experience will lead to a corresponding increase in their level of involvement in cassava production activities in the study area. This is probably because, with more experience they are better informed in role sharing for effective and efficient use of resources in the farm. The result is in consonance with the findings of Osondu, Emerole and Anyiro (2014) as they reported that farmers count more on their experience than educational attainment in order to increase in their productivity as a result of level of involvement in cassava production activities.

Similarly, the coefficient of education of the female farmers was positive and significant at $5.0 \%$ level of probability. This implies that any increase in level of education will lead to a corresponding increase in the level of involvement of women in cassava production activities in the study area. With more education farmers are more likely to adopt new technology and innovations, thereby increasing their level of involvement in cassava production activities. The 
result corroborates with that of Abudu, Haruna, Idehen and Janiley (2014) who reported that education positively influence participation of farmers in agricultural activities.

\section{Gender Difference in Level of Involvement in Cassava Production Activities}

Table 4 shows test of significant difference in the level of involvement of male and female farmers in cassava production activities in the study area. The table shows mean level of involvement of 19.61 and 21.57 for the male and female farmers respectively. The results imply that there was a significant difference in men and women's involvement in cassava production activities in the study area. Result shows that the women were more involved in cassava production activities than the men. This result conforms the findings of Ejechi (2015); Adeoye and Ugala (2017) as they observed that cassava was mostly cultivated by women in South East, Nigeria.

Table 4: Test of significant difference in level of involvement of male and female cassava farmers in cassava production activities in the study area

\begin{tabular}{lccc}
\hline Variables & Mean & Standard Deviation & Z-test \\
\hline Level of involvement & & & \\
Male & 19.6167 & 2.5184 & $-3.6205^{*}$ \\
Female & 21.5667 & 3.3262 & \\
\hline
\end{tabular}

Source: Field Survey, 2018

\section{CONCLUSION AND RECOMMENDATIONS}

The result from the study has proven that women farmers were more involved in cassava production than their men counterparts. Farmers also sourced cassava production technologies from Agricultural Development Programme and fellow farmers. Household size, farm income and farm size influenced male involvement in cassava production activities while marital status, farming experience and education influenced female involvement in cassava production activities in the study area.

The study therefore recommends

i. Formulation of policies, planning and preparation of projects/programmes by relevant agencies that would encourage gender sensitivity on cassava production is advocated.

ii. Since farm size influences male farmers involvement in cassava production activities, there is need to make more land available to both farmer groups in the study area. This will be achieved through land reform policies of the government. 
iii. There is need to encourage experienced farmers to remain in farming by accessing farm inputs such as improved cassava cuttings and agrochemicals. This will be achieved through enlightenment programmes organized by relevant agencies.

iv. Policies on free and affordable education especially to the women farmers should be formulated. This will enhance their ability to access and process information on new cassava technologies for enhanced productivity.

\section{REFERENCES}

Abudu, S., Haruna S. K, Idehen, O. F. and Janiley A.A. (2014). Adoption of Recommended Cassava Production among Farmers in Edo State, Nigeria. Proceedings of $19^{\text {th }}$ Annual National Conference of the Agricultural Extension Society of Nigeria Held at Federal University of Technology (FUTO), Owerri, Imo State, $27^{\text {th }}-30^{\text {th }}$ April.

Adeoye, S. O. and Ugada, H.I. (2017). Smallholder Food Crop Farmer's Participation in Bank of Agriculture (BOA) Loan Scheme in Ogun State, Nigeria. Agrosearch, 17(2):51 - 56

Agarwal, B. (2017). Gender, Property and Land Rights: Bridging a Critical Gap in Economic Analysis and Policy 1. In Gender and Right Routledge, Pp. 119-149.

Aniedu, O. C. (2016). Determinants of Adoption of Recommended Yam Production Technologies among Farmers in Ebonyi State, Nigeria. The Nigerian Agricultural Journal, 47(1): $275-281$.

Arifin, A. A. and Nirawal, M. A. B. (2018). Efficiency and Income of Rice Farming in Rain- Fed Lowland. International Journal of Scientific and Technological Research, 7(2): 32 55 .

Badiru, I.O and Yekini, O.T. (2015). Programme Format Preferences of Rural Development Broad Caster and Listeners in South-Western, Nigeria. Nigerian Journal of Rural Extension and Development, 9(1): 47 - 52.

Effiong, E. O., Ayanam, B. M. and Umoh, G. S. (2012). Analysis of Performance of Cooperative Cassava Farmers in Uyo Local Government Area of Akwa Ibom State, Nigeria. Nigerian Journal of Agriculture, Food and Environment, 8(3):39-46.

Ejechi .M. E. (2015) Determinants of Adoption of Cassava Technologies by Male Farmers in Nasarawa State, Nigeria. Journal of Agricultural Extension, 19(1):124 - 128 
Etuk, E. A., Udoe, P. O. and Okon, I. I. (2018). Determinants of Livelihood Diversification among Farm Households in Akamkpa Local Government Area, Cross River State, Nigeria. Agrosearch, 18(2):88 - 110.

Federal Ministry of Agriculture and Rural Development (FMA\&RD) (2018). Agricultural Transformation Agenda. Federal Ministry of Agriculture and Rural Development, Abuja, Nigeria.

International Institute for Tropical Agriculture (IITA) (2010). Annual Report of IITA, Ibadan, Nigeria. Cassava the Multipurpose Crop.

Lagat, J.K., and Maina, M.C. (2017). A Gender and Decent Work Analysis of Cassava Production and on - Farm Processing, in Kuria West Sub-county, Kenya. African Journal of Agricultural Research, 12(13), 2533-2544.

Michael, K. K. (2014) The Effect of Improved Commercial Bank Services on Saving and Credit Cooperative Societies Membership: A Case Study of Murang'a Town, Kenya. International Journal of Academic Research in Economics and Management Sciences, 3(4):2226-3624.

National Root Crops Research Institute (NRCRI) (2012). Annual Report on Cassava Production, Vol. 12, Pp. 7.

Nwakor, F. N., ljioma, J. C., Emerole, C. O., Ekedo, T. O., Amamgbo, L. E. F and Asumugha, G. N. (2016). Differentials in the Adoption of Cocoyam Technologies among Farmers in South Eastern, Nigeria. The Nigerian Agricultural Journal, 47(2): 12 - 20.

Nwaobiala, C. U. (2017): Effect of Agricultural Extension Delivery Methods on Arable Crops Farmers Cropping Systems in Kaduna State, Nigeria. Scientific Papers Series Management, Economic Engineering in Agriculture and Rural Development Journal, 17 (3): $225-230$.

Nwaobiala, C. U. (2018). Farmers' Adoption of Cassava Agronomic Practices and Intercrop Technologies in Abia and Imo States, Nigeria. Journal of Agricultural Extension, 22(2):82 - 96.

Obinna, L. O. and Nwaobiala, C. U. (2015). Gender Differentials in Rural Household Decision Making among Small Scale Cassava Farmers in Abia State, Nigeria. Nigerian Journal of Agriculture, Food and Environment, (NJAFE) 11(2):138-145. www.njafe.org. 
Odebode, S.O and Adetunji, T.A (2015). Gender Differentials of Cassava Processing Activities among cassva processors in Ogun State, Nigeria. Nigerian Journal of Rural Extension and Development, 9(1):1 - 6 .

Okoroafor, K. M. and Nwaobiala, C. U. (2014). Effectiveness of cassava women processors in value addition technologies in Abia State, Nigeria. International Journal of Agricultural Science, Research and Technology in Extension and Education Systems (IJASRT in EESs) www.ijasit.webs.com 4(3): 137 - 142.

Okpara, S. (2015). Role of Gender in Cassava Processing in Enugu State, Nigeria. Bangladesh Journal of Agricultural Research, 35(3): 387-394.

Olaoye, O. A. (2014). Potentials of the Agro Industry towards Achieving Food Security in Nigeria and other Sub-Saharan African Countries. Journal of Food Security, 2(1):33-41.

Onyeneke, R.U, Nwala, A.C. Akunbuilo, C.J.C, Mmaju, C. J. Nwosu, C.S and Aligbe, J. O. (2016). Comparative Analysis of Adoption of Improved Cassava Technologies by Cooperators and Non - Cooperators in Imo State, Nigeria. The Nigeria Agricultural Journal, 47(1): $282-291$.

Osondu, C. K. Ezeh, C. I. Emerole C. O. and Anyiro C. O. (2014). Comparative Analysis of Technical Efficiency of Small Holder Fadama II and Fadama III Cassava Farmers in Imo State, Nigeria. Nigerian Journal of Rural Extension and Development, 8 (2):26 -37 .

Tijani, H., Tijani, B. A. and Audu, A. (2018). Socioeconomic Characteristics of Vegetable Farmers Awareness of Safety Measures in Pesticides Use in Jere Local Government Area, Borno State, Nigeria. Agrosearch, 18(1):53 - 65.

Umunakwe, P. C., Nnadi, F. N., Ani, A. O., Anaeto, F. C. and Okerekke-Ejiogu, E. N. (2016). Constraints to Cassava Processing among Rural Women in Imo State, Nigeria Proceedings of $21^{\text {st }}$ National Conference of Agricultural Extension Society of Nigeria held at University of Ibadan, Oyo State, Nigeria, $18^{\text {th }}-21^{\text {st }}$ April, Pp. 53-61. 